\title{
Physiological and sanitary quality of soybean seeds harvested at different periods and submitted to storage ${ }^{1}$
}

\author{
Alan Mario Zuffo², Joacir Mario Zuffo Júnior, \\ Everton Vinicius Zambiazzi ${ }^{4}$, Fábio Steiner ${ }^{2}$
}

\section{ABSTRACT}

Delayed harvesting may affect the physiological quality of soybean seeds, due to adverse conditions in the field. This study aimed to evaluate the physiological and sanitary quality of soybean seeds (BRS $820 \mathrm{RR}^{\circledR}$ cultivar) harvested at eight periods $(0 ; 5 ; 10 ; 15 ; 20 ; 25 ; 30$; and 35 days after the $\mathrm{R}_{8}$ phenological stage - full maturity) and stored for two periods ( 0 and 8 months). The following evaluations were carried out: moisture content, germination and emergence rate, emergence speed index, total plant dry mass, accelerated aging, electrical conductivity, mechanical damage, vigor and viability (tetrazolium) and sanitary quality of the seeds. The delayed harvesting of soybean seeds from 10 days after $R_{8}$ impairs seed vigor and germination, in addition to increase the incidence of pathogens. Regardless of the harvesting period, the soybean seeds stored for eight months showed a reduction in their physiological quality, with an increase in the incidence of Phomopsis spp.

KEYWORDS: Glycine $\max ($ L.) Merrill; pathogens; seed health.

\section{INTRODUCTION}

Soybean [Glycine max (L.) Merrill] crops are prominent in the world agribusiness, and Brazil is among the largest producers and exporters. To reach such a high representativeness, it is crucial that the soybean seed market produce high quality seeds that guarantee vigorous crops. In the 2016/2017 harvesting, the Brazilian seed industry traded more than 5 million tons of soybean seeds (Carvalho et al. 2017).

The quality of soybean seeds is an extremely important factor for the expansion of soybean crops in tropical and subtropical regions (Lima et al. 2007).

In the soybean seed production, all stages of the process are relevant to obtain a high quality material,

\section{RESUMO}

Qualidade fisiológica e sanitária de sementes de soja colhidas em diferentes épocas e submetidas a armazenamento

$\mathrm{O}$ atraso na colheita pode afetar a qualidade fisiológica de sementes de soja, devido à ocorrência de condições adversas no campo. Objetivou-se avaliar a qualidade fisiológica e sanitária de sementes de soja (cultivar BRS $\left.820 \mathrm{RR}^{\circledR}\right)$ colhidas em oito épocas $(0 ; 5 ; 10 ; 15$; 20; 25; 30; e 35 dias após o estádio fenológico $\mathrm{R}_{8}$ - maturação plena) e armazenadas por dois períodos ( 0 e 8 meses). Foram efetuadas as seguintes avaliações: grau de umidade, taxa de germinação e emergência, índice de velocidade de emergência, fitomassa seca total da planta, envelhecimento acelerado, condutividade elétrica, dano mecânico, vigor e viabilidade (tetrazólio) e qualidade sanitária das sementes. O retardamento na colheita de sementes de soja a partir de 10 dias após $\mathrm{R}_{8}$ prejudica o vigor e a germinação das sementes, além de aumentar a incidência de patógenos. Independentemente da época de colheita, o armazenamento das sementes de soja por oito meses culminou em redução na sua qualidade fisiológica, com incremento na incidência de Phomopsis spp.

PALAVRAS-CHAVE: Glycine $\max ($ L.) Merrill; patógenos; sanidade de sementes.

and harvesting is naturally a crucial one. Soybean seeds reach their maximum dry mass accumulation and maximum physiological quality at the $\mathrm{R}_{7}$ stage (beginning maturity) (Fehr et al. 1971), time when harvesting should be performed. However, because of the high moisture content of the seeds at that stage, harvesting is performed at the $\mathrm{R}_{8}$ stage, when $95 \%$ of the pods are mature in color (Diniz et al. 2013a).

In many cases, the ideal harvesting time is exceeded due to the vast extension of planted areas and insufficient harvesters, or due to high rainfall rates during the harvesting process. Therefore, seeds may remain exposed in the field for longer periods.

Soybean seeds, when stored in the field, are subject to adverse conditions such as climatic

1. Manuscript received in Jun./2017 and accepted for publication in Sep./2017 (http://dx.doi.org/10.1590/1983-40632016v4747576).

2. Universidade Estadual do Mato Grosso do Sul, Cassilândia, MS, Brasil.E-mails: alan_zuffo@hotmail.com, steiner@uems.br.

3. Universidade do Estado de Mato Grosso, Nova Xavantina, MT, Brasil. E-mail: zuffojr@gmail.com.

4. Universidade Federal de Lavras, Departamento de Agricultura, Lavras, MG, Brasil._E-mail: everton_zambiazzi@hotmail.com. 
variations, insects and pathogens, which may compromise their physiological quality.

In the period between physiological maturity and harvesting, soybean seeds may be damaged because of alternating wet and dry environmental conditions, which are even more expressive in tropical regions, where it is predominantly warm and humid (Castro et al. 2016). In general, delayed harvesting associated with relative air humidity variation causes several damages to the seeds, such as cracks and wrinkles on the seed coat, increasing the deterioration process, given the facilitated penetration of pathogens and increased exposure of the embryonic tissue to the environment (Marcandalli et al. 2011).

In future scenarios, characterized by landuse intensification, early-cycle cultivars and early sowing and harvesting, associated with adverse meteorological events, it can be assumed that production losses and low quality seeds owing to delayed harvesting may become more frequent (Tsukahara et al. 2016).

This study aimed to evaluate the physiological and sanitary quality of soybean seeds harvested in eight periods and stored for two periods.

\section{MATERIAL AND METHODS}

The experiment was carried out at the Fazenda Muquém, in Lavras, Minas Gerais state, Brazil ( $21^{\circ} 14$ 'S, $45^{\circ} 00^{\prime} \mathrm{W}$ and altitude of $918 \mathrm{~m}$ ), in the $2013 / 2014$ season. The tests of physiological and sanitary quality of the seeds were carried out at a laboratory of the Universidade Federal de Lavras.

The soil of the experimental area is classified as Rhodic Hapludox (Latossolo Vermelho Eutroférrico, under the Brazilian classification), and the physical and chemical properties (Table 1) were determined according to Embrapa (2009).

The regional climate is Cwa, according to the Köppen classification, with annual average temperature of $19.3{ }^{\circ} \mathrm{C}$ and annual rainfall of $1,530 \mathrm{~mm}$ (Dantas et al. 2007). During the growing season of the soybean crop, data concerning air temperature, relative humidity and rainfall were collected from an automatic weather station of the Brazilian National Institute of Meteorology (Inmet), and are presented in Figure 1a, while the climatic conditions during seed harvesting times are shown in Figure 1b.

The experiment was arranged in a randomized block design, in an $8 \times 2$ factorial scheme, being eight harvest times $[0 ; 5 ; 10 ; 15 ; 20 ; 25 ; 30$; and 35 days
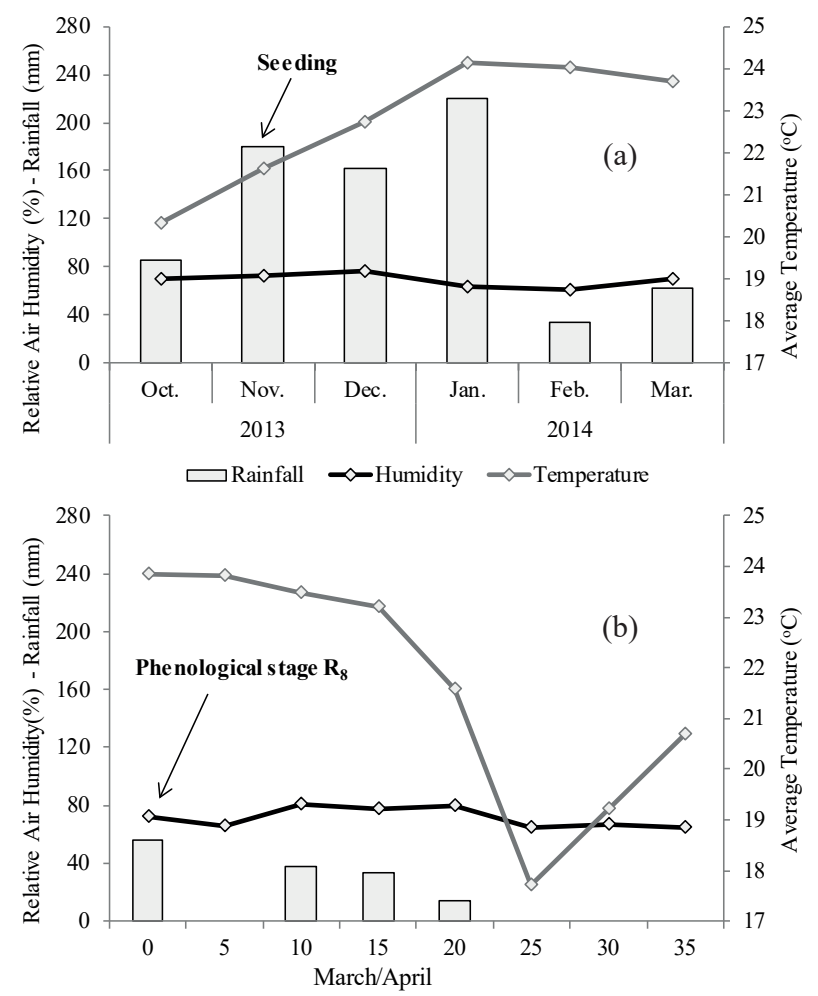

Figure 1. Total monthly rainfall $(\mathrm{mm})$, relative humidity $(\%)$ and average air temperature $\left({ }^{\circ} \mathrm{C}\right)$, in the $2013 / 2014$ cropping season, during the soybean seed production (a) and at the seed harvest times (b). Source: Brazilian National Institute of Meteorology (Inmet).

Table 1. Soil chemical and physical properties (0.0-0.20 m layer) before the beginning of the experiment.

\begin{tabular}{|c|c|c|c|c|c|c|c|c|c|c|}
\hline $\mathrm{pH}$ & $\mathrm{Ca}^{2+}$ & $\mathrm{Mg}^{2+}$ & $\mathrm{Al}^{3+}$ & $\mathrm{H}^{+}+\mathrm{Al}^{3+}$ & SB & $\mathrm{CEC}$ & $\mathrm{P}$ & $\mathrm{K}$ & $\mathrm{OM}$ & $\mathrm{V}$ \\
\hline $\mathrm{H}_{2} \mathrm{O}$ & 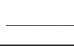 & 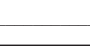 & $-\mathrm{cm}$ & $\mathrm{Im}^{-3}-$ & & - & $-\mathrm{mg}$ & & dag $\mathrm{kg}^{-1}$ & $\%$ \\
\hline 6.4 & 5.0 & 1.4 & 0.0 & 2.9 & 6.7 & 9.6 & 11.46 & 118 & 3.41 & 70 \\
\hline $\mathrm{Zn}$ & $\mathrm{Mn}$ & $\mathrm{Cu}$ & $\mathrm{B}$ & $\mathrm{Fe}$ & $\mathrm{S}$ & Clay & Silt & Sand & \multirow{2}{*}{\multicolumn{2}{|c|}{ Textural class }} \\
\hline \multicolumn{6}{|c|}{$\mathrm{mg} \mathrm{dm}^{-3}$} & \multicolumn{3}{|c|}{ dag kg-1 $^{-1}$} & & \\
\hline 4.97 & 31.7 & 1.4 & 0.17 & 34.81 & 4.7 & 64 & 20 & 16 & \multicolumn{2}{|c|}{ Clayey } \\
\hline
\end{tabular}

$\mathrm{H}+\mathrm{Al}$ : potential acidity; SB: sum of bases; $\mathrm{CEC}$ : cation exchange capacity at $\mathrm{pH}$ 7.0; OM: organic matter; V: soil base saturation. 
after the stage $\mathrm{R}_{8}$ (when $95 \%$ of pods have typical coloration of mature pods), according to Fehr et al. (1971)], and two storage times (0 and 8 months), with four replications.

Soybean [Glycine max L. (Merrill.), BRS 820 $\mathrm{RR}^{\circledR}$ cultivar] was sown in November 2013, at a row spacing of $0.50 \mathrm{~m}$ and rate of 14 seeds $\mathrm{m}^{-1}$. Seeds were treated with pyraclostrobin + methyl thiophanate + fipronil (Standak Top ${ }^{\circledR}$ ), at the rate of $2.0 \mathrm{~mL}$ of the commercial product per kilogram of seeds, and inoculated with Bradyrhizobium japonicum strains SEMIA 5079 and SEMIA 5080 (Nitragin Cell Tech ${ }^{\circledR}$ ), at $3.0 \mathrm{~mL}$ of the commercial product per kilogram of seeds. Base fertilization was carried out by applying $350 \mathrm{~kg} \mathrm{ha}^{-1}$ of a $02-30-20$ formulation at sowing. Each experimental unit consisted of four $5.0 \mathrm{~m}$-long soybean rows, and two central rows were considered as useful area, excluding $1.0 \mathrm{~m}$ from each end.

During the soybean growing season, the management of weeds, pests and diseases was performed using the following products: glyphosate, pyraclostrobin + epoxiconazole, azoxystrobin + ciproconazole, teflubenzurom, chlorpyrifos and cypermethrin. All the chemicals used in the present investigation were of analytical grade.

After harvesting, plants were taken to the shade and, when the water content of the seeds ranged between $12 \%$ and $13 \%$, they were mechanically threshed in a grain thresher (Vencedora Maqtron ${ }^{\circledR}$ model B-380). After cleaning the seeds, the 1,000seed mass, according to Brasil (2009), and the seed yield $\left(\mathrm{kg} \mathrm{ha}^{-1}\right)$, with correction for $13 \%$ of wet basis, were determined. Subsequently, the seeds were sieved through round hole sieves with diameters of $6.00 \mathrm{~mm}$, and then separated into two parts: the first was used for evaluations without storage time and the second was placed in Kraf-type paper bags and kept in a laboratory environment with temperature of $25 \pm 0.8^{\circ} \mathrm{C}$, for 8 months. Afterwards, seeds were submitted to the following tests:

a) Water content: after drying in the shade, the water content $(\%)$ of seeds was determined by the oven dry method at $105{ }^{\circ} \mathrm{C}\left( \pm 3{ }^{\circ} \mathrm{C}\right)$, for $24 \mathrm{~h}$ (Brasil 2009);

b) Emergence: carried out in a greenhouse, using 4 replications of 50 seeds of each treatment. The seeds germinated in plastic trays $(42 \mathrm{~cm} \times 28 \mathrm{~cm} \times$ $6 \mathrm{~cm}$ ) containing soil and sand, at the proportion of $2: 1(\mathrm{v} / \mathrm{v})$. The water content of the substrate was maintained at $70 \%$ of the field capacity, with daily irrigations. The trays were maintained under greenhouse conditions at a temperature of $25^{\circ} \mathrm{C}$ $\left( \pm 2{ }^{\circ} \mathrm{C}\right)$. Counts were performed daily and at the end of the 14th day, and the emergence rate index was calculated according to the formula proposed by Maguire (1962);

c) Plant dry matter: for determining the dry matter production of shoots and roots, all seedlings obtained at the end of the seedling emergence tests (14th day) were removed from the trays, dried in a forced air circulation oven for 3 days, at $60{ }^{\circ} \mathrm{C}$, and then weighed. The results were expressed in $\mathrm{mg}$ seedling $^{-1}$;

d) Germination: four replicates of 50 seeds from each treatment were distributed between three sheets of paper towel moistened with distilled water, in the proportion of 2.5 times the weight of the dry paper towel. After the towels were rolled up, they were taken to a germinator set to a constant temperature of $25^{\circ} \mathrm{C}$. Evaluations were carried out at the 8th day after the test installation (Brasil 2009);

e) Accelerated aging: seeds were placed on an aluminum screen fixed inside plastic germination boxes $(11.0 \mathrm{~cm} \times 11.0 \mathrm{~cm} \times 3.0 \mathrm{~cm})$ containing $40 \mathrm{~mL}$ of distilled water (Marcos Filho 1999). The germination boxes were kept in a BOD incubator at $41{ }^{\circ} \mathrm{C}$, for $48 \mathrm{~h}$. After this period, 200 seeds from each treatment were divided into four replications of 50 seeds, and germinated as previously described (germination test). The evaluation was made on the fifth day after sowing, and the percentage of normal seedlings was calculated (Brasil 2009);

f) Electrical conductivity: four replicates of 50 seeds of each treatment were placed in $300 \mathrm{~mL}$ plastic cups and weighed on an analytical scale (0.001 g accuracy). Then, $75 \mathrm{~mL}$ of distilled water were added to each container. The containers were placed in a BOD incubator at a constant temperature of $25^{\circ} \mathrm{C}$. After $24 \mathrm{~h}$ of incubation, the seeds were gently agitated for homogenization of the solution, and the electrical conductivity was measured with a conductivity meter (MS TECNOPON ${ }^{\circledR}$ mCA150). The results were expressed as $\mu \mathrm{S} \mathrm{cm}^{-1} \mathrm{~g}^{-1}$ (Krzyzanowski et al. 1999);

g) Mechanical damage (sodium hypochlorite): carried out according to Krzyzanowski et al. (2004). Four replicates of 50 seeds per treatment were immersed for $10 \mathrm{~min}$ in a $2 \%$ solution of sodium hypochlorite. Subsequently, the solution excess was discarded and the seeds distributed on sheets of 
paper towel to determine the percentage of swollen (damaged) seeds;

h) Tetrazolium: the test was conducted on two sub-samples of 50 seeds per treatment. The pre-conditioning of seeds was carried out on moist germination paper towel, for $16 \mathrm{~h}$, at $25^{\circ} \mathrm{C}$. Afterwards, the seeds were transferred to plastic cups with a $0.075 \%$ solution of 2,3,5-triphenyl tetrazolium chloride and stained in a dark chamber at $40{ }^{\circ} \mathrm{C}$, for $3 \mathrm{~h}$. Then, the seeds were washed in running water and each seed was analyzed individually by examining the location and extent of external and internal damages (mechanical damage, weathering and stink bug feeding damage), by cutting longitudinally the seeds along the embryonic axis, and the seed coat was removed (França-Neto et al. 1998);

i) Seed health: evaluated by the Blotter-test method, with 5 replicates of 40 seeds. The plates were kept in an incubation room at $20^{\circ} \mathrm{C}$ and photoperiod of $12 \mathrm{~h}$, for 7 days, and then evaluated for the presence of pathogens associated to the seeds. Seed health was evaluated through the confidence interval for proportions (Ramalho et al. 2012).

Data were submitted to analysis of variance (Anova) and, when significant, the means were compared by the LSD test, at $5 \%$, using the Sisvar ${ }^{\circledR}$ software, version 5.3 for Windows (Statistical Analysis Software, UFLA, Lavras, MG, BRA). For the harvesting times, the regression analysis was used, and the significant equations with the highest coefficients of determination (test $F, p<0.05$ ) were adjusted using the SigmaPlot 11.0 software for Windows (Systat Software, Inc., San Jose, CA, USA).

\section{RESULTS AND DISCUSSION}

The storage of soybean seeds for 8 months significantly affected $(\mathrm{p}<0.01)$ all studied variables (Table 2). However, in terms of moisture content of the seeds harvested in different periods of time, no significant differences were detected. These results are similar to the findings of Lima et al. (2007), who evaluated the delayed harvesting of different soybean genotypes and found no statistical difference for this parameter. For the harvesting period x storage interaction, significance was noticed only for the germination rate, emergence speed index, accelerated aging and tetrazolium vigor test.

In general, the soybean seeds stored for 8 months showed a greater reduction of moisture content, physiological quality and seedling vigor, evinced by the variables germination rate, emergence rate, emergence speed index, total dry mass, accelerated aging, electrical conductivity, hypochlorite, tetrazolium vigor and viability tests (Table 3). These results corroborate the findings of Barbosa et al. (2010), who observed a loss of vigor in soybean seeds after 6 months of storage. Similarly, Almeida et al. (2010) observed a decrease in the soybean germination rate after 180 days of storage under environmental conditions.

The decrease in the moisture content may be attributed to the permeability of the packages storing the seeds, which allowed the exchange of water vapor with the environment. This occurs because seeds and grains are hygroscopic and subject to sorption processes, i.e., their moisture content is always in equilibrium with relative air humidity and air

Table 2. Analysis of variance for moisture content (MC), germination rate (GERM), emergence rate (EMER), emergence speed index (ESI), total dry mass (TDM), accelerated aging (AA), electrical conductivity (EC), mechanical damage by sodium hypochlorite (HYPO), tetrazolium vigor test $\left(\mathrm{TZ}_{1-3}\right)$ and tetrazolium viability test $\left(\mathrm{TZ}_{1-5}\right)$, obtained in different harvesting times, for the BRS $820 \mathrm{RR}^{\circledR}$ soybean cultivar.

\begin{tabular}{|c|c|c|c|c|c|}
\hline Causes of variation & $\mathrm{MC}$ & GERM & EMER & ESI & TDM \\
\hline F-test & \multicolumn{5}{|c|}{ Probability $>\mathrm{F}^{1}$} \\
\hline Storage (S) & $<0.000$ & $<0.000$ & $<0.000$ & $<0.000$ & $<0.000$ \\
\hline Harvest period $(\mathrm{H})$ & 0.996 & $<0.000$ & $<0.000$ & $<0.000$ & $<0.000$ \\
\hline Interaction $(\mathrm{S} \times \mathrm{H})$ & 0.999 & $<0.000$ & 0.609 & $<0.000$ & 0.109 \\
\hline \multirow[t]{2}{*}{ CV $(\%)$} & 13.13 & 8.01 & 7.46 & 10.53 & 9.38 \\
\hline & AA & $\mathrm{EC}$ & HYPO & $\mathrm{TZ}_{1-3}$ & $\mathrm{TZ}_{1-5}$ \\
\hline Storage (S) & $<0.000$ & $<0.000$ & $<0.000$ & $<0.000$ & $<0.000$ \\
\hline Harvest period $(\mathrm{H})$ & $<0.000$ & $<0.000$ & $<0.000$ & $<0.000$ & $<0.000$ \\
\hline Interaction $(\mathrm{S} \times \mathrm{H})$ & $<0.000$ & 0.473 & 0.203 & $<0.000$ & 0.453 \\
\hline $\mathrm{CV}(\%)$ & 19.03 & 9.42 & 22.90 & 7.80 & 9.68 \\
\hline
\end{tabular}


Table 3. Average values of moisture content (MC), germination rate (GERM), emergence rate (EMER), emergence speed index (ESI), total dry mass (TDM), accelerated aging (AA), electrical conductivity (EC), mechanical damage by sodium hypochlorite (HYPO), tetrazolium vigor $\left(\mathrm{TZ}_{1-3}\right)$ and viability test $\left(\mathrm{TZ}_{1-5}\right)$, obtained in different harvesting times, for the BRS $820 \mathrm{RR}^{\circledR}$ soybean cultivar.

\begin{tabular}{|c|c|c|c|c|c|}
\hline \multirow{2}{*}{ Storage (months) } & $\mathrm{MC}$ & GERM & EMER & \multirow{2}{*}{ ESI } & TDM \\
\hline & & $-\%$ & & & $\mathrm{mg}^{-1}$ \\
\hline 0 & $10.36 \mathrm{a}^{*}$ & $84.12 \mathrm{a}$ & $83.81 \mathrm{a}$ & $37.28 \mathrm{a}$ & $114.25 \mathrm{a}$ \\
\hline 8 & $8.30 \mathrm{~b}$ & $44.09 \mathrm{~b}$ & $76.18 \mathrm{~b}$ & $17.39 \mathrm{~b}$ & $97.37 \mathrm{~b}$ \\
\hline \multirow{2}{*}{ Storage (months) } & AA & $\mathrm{EC}$ & HYPO & $\mathrm{TZ}_{1-3}$ & $\mathrm{TZ}_{1-5}$ \\
\hline & $\%$ & $\mu \mathrm{S} \mathrm{cm}^{-1} \mathrm{~g}^{-1}$ & \multicolumn{3}{|c|}{$\%$} \\
\hline 0 & $40.68 \mathrm{a}$ & $108.15 \mathrm{~b}$ & $6.81 \mathrm{~b}$ & $79.28 \mathrm{a}$ & $82.18 \mathrm{a}$ \\
\hline 8 & $18.50 \mathrm{~b}$ & $133.77 \mathrm{a}$ & $24.06 \mathrm{a}$ & $63.28 \mathrm{~b}$ & $75.87 \mathrm{~b}$ \\
\hline
\end{tabular}

* Means followed by the same letter do not differ from each other, according to the $\mathrm{F}$ test.

temperature (Smaniotto et al. 2014). However, the loss of vigor in the soybean seeds stored for 8 months may be related to the biochemical transformations occurring in the seeds, since, according to Smaniotto et al. (2014), soybean seeds tend to lose vigor and germination capacity during storage, due to lipid peroxidation.

The physiological quality of the soybean seeds was affected by the delayed harvesting. A quadratic behavior was observed for emergence (Figure 2a), seedling dry mass (Figure $2 b$ ), electrical conductivity (Figure 2c), mechanical damage (Figure 2d) and tetrazolium viability test (Figure $2 \mathrm{e}$ ). As a result, the harvesting at the $\mathrm{R}_{8}$ stage demonstrated higher values for emergence, dry seedling mass and tetrazolium viability rates, and lower values for electrical conductivity and mechanical damages. After a 10-day harvesting delay, the seeds started to deteriorate, resulting in a marked decrease in seed quality, which was intensified by the delay of up to 35 days. These results are similar to those found by Diniz et al. (2013b), who observed higher mean values for the emergence rate of seeds harvested at the $\mathrm{R}_{8}$ stage, decreasing from the day 15 after emergence.

For Minuzzi et al. (2010), the qualitative reduction of the physiological parameters may be related to the seed respiratory process, which, in turn, may be favored by situations of frequent rainfall during the pre-harvesting period. Therefore, the precipitations caused at 10,15 and 20 days after the $\mathrm{R}_{8}$ stage resulted in the acceleration of the physiological quality deterioration process of the soybean seeds from day 10 of delayed harvesting. According to Marco Filho (2005), the alternation of dry and wet periods predisposes the occurrence of damages to the seed integument, due to the expansions and contractions after successive wetting and drying cycles.
The minimum germination rate of soybean seed lots in Brazil is $80 \%$ (Brasil 2013). Thus, seeds harvested up to 15 days after the $\mathrm{R}_{8}$ stage showed satisfactory germination rates (Figure $3 \mathrm{a}$ ), when the seeds were not stored. However, regardless of the harvesting period, after 8 months of storage, the soybean seeds showed germination rates below the marketing standard, with drastically reduced rates for seeds harvested after 15 days of delay. These results are similar to the findings of Xavier et al. (2015), who verified a higher germination potential after 7 days, at the $\mathrm{R}_{8}$ stage. According to França-Neto et al. (2010), seeds with germination rates below the minimum marketing standards result in low-vigor seedlings and no possibility of being competitively established in the field.

With respect to the marketing requirements, the germination rate alone is not sufficient, so other vigor indicators, such as seedling dry mass (Figure 2b), emergence speed index (Figure 3b), accelerated aging (Figure $3 \mathrm{c}$ ) and tetrazolium vigor test (Figure 3d), are required. For these parameters, no harmful effect was observed up to 10 days of delay in the non-stored seeds and up to 8 months in the stored seeds. However, the non-stored seeds obtained higher average values for all the seed quality variables (Table 3 ).

Regarding the seed sanitary evaluation, the pathogens Colletotrichum sp., Phomopsis sp., Penicillium sp., Aspergillus sp., Fusarium sp., Semitectum sp., Cercospora kikuchii and Alternaria sp. were identified in newly harvested seeds (Figure 4a), as well as in stored seeds (Figure 4b). The pathogens observed in the soybean seeds in this study are the highest occurring pathogens in Brazil. According to Danielli et al. (2011), these pathogens 
are of greater importance, as they cause significant losses in crops and reduce the quality of soybean seeds.

According to Marcos Filho (2005), fungi of the genus Fusarium sp., Colletotrichum sp. and Alternaria sp. are known as field fungi, and their
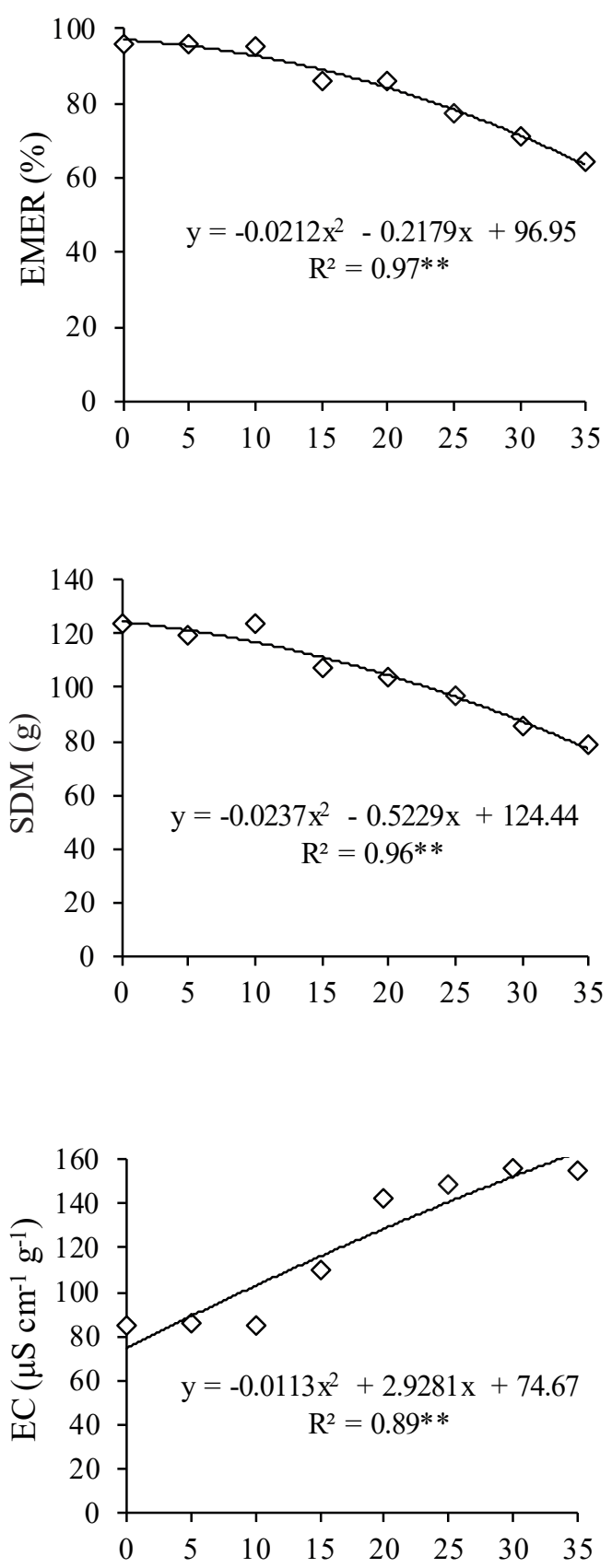

(b)

(c) occurrence is accentuated when the seeds remain in the field for a relatively long period after maturity, exposed to a warm and humid environment, whereas Penicillium sp. and Aspergillus sp. are storage fungi, which contaminate the seeds after harvesting, especially in cases of delay. Thus, greater proportions of these pathogens were observed in each seed storage period (Figures $4 a$ and $4 b$ ).

In general, a higher incidence of pathogens was observed in seeds harvested after 15 days of delay (Figure 4c). These findings confirm the data obtained by Diniz et al. (2013a), for soybean seeds harvested at 15 or 30 days after the reproductive $\mathrm{R}_{8}$ stage, which showed a significant increase in fungal infection, especially of the genus Fusarium spp., Phomopsis spp. and Epicoccum spp. Therefore, the decrease in the germination (Figure 3a) and emergence (Figure 2a) rates in seeds harvested after 15 days of delay may also be related, at least in

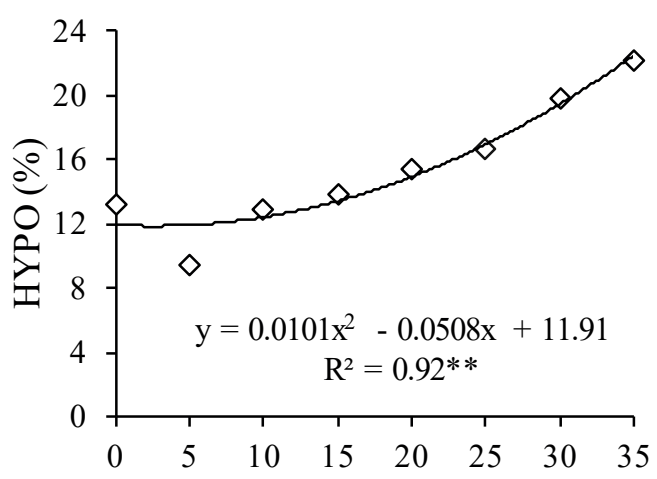

(d)

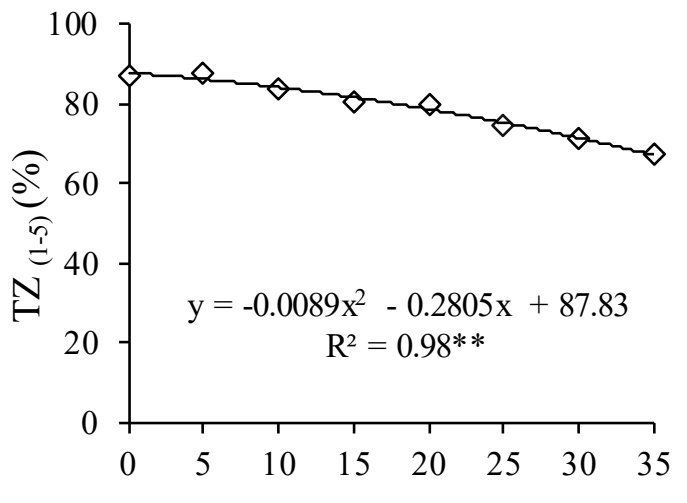

(e)

Figure 2. Average values for emergence (EMER; a), seedling dry mass (SDM; b), electrical conductivity (EC; c), mechanical damage by sodium hypochlorite (HYPO; d) and tetrazolium viability $\left(\mathrm{TZ}_{1-5} ; \mathrm{e}\right)$, obtained in different harvesting and seed storage periods, for the BRS $820 \mathrm{RR}^{\circledR}$ soybean cultivar. 
$0=-0.0182 \mathrm{x}^{2}-0.1065 \mathrm{x}+94.021 \mathrm{R}^{2}=0.98 * *$ $\square 8=0.0064 \mathrm{x}^{2}-2.1417 \mathrm{x}+79.042 \mathrm{R}^{2}=0.85 * *$

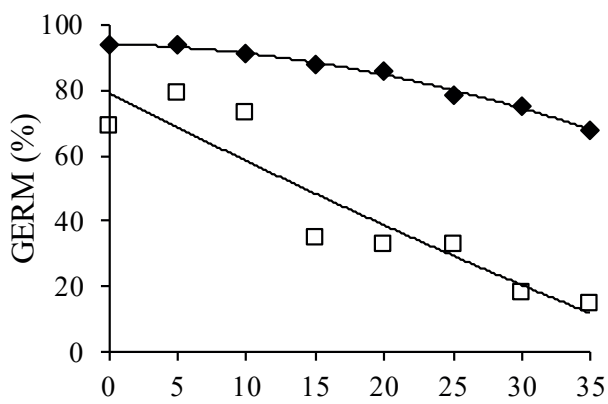

$\diamond 0=-0.0190 \mathrm{x}^{2}-0.719 \mathrm{x}+61.917 \mathrm{R}^{2}=0.88 * *$ $\square 8=0.0195 \mathrm{x}^{2}-1.5595 \mathrm{x}+37.25 \mathrm{R}^{2}=0.96 * *$

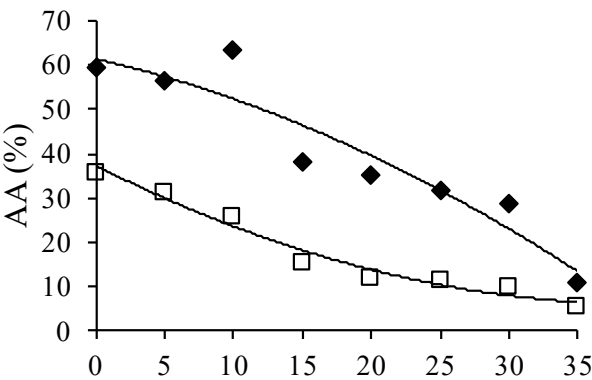

(a)

$\bullet 0=-0.0037 \mathrm{x}^{2}-0.5232 \mathrm{x}+48.041 \mathrm{R}^{2}=0.91 * *$ $\square 8=0.0051 \mathrm{x}^{2}-0.0251 \mathrm{x}+20.073 \mathrm{R}^{2}=0.95 * *$

(b)

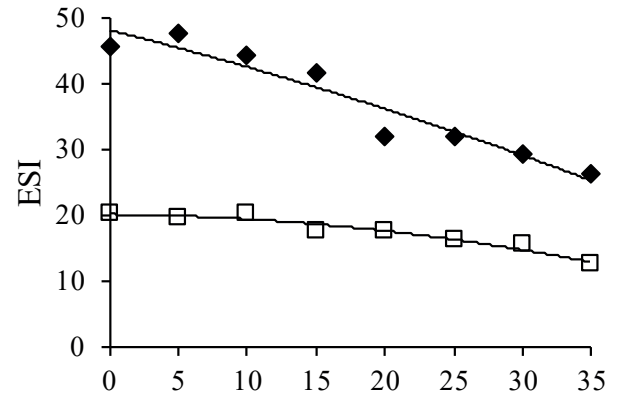

$\bullet 0=0.0122 \mathrm{x}^{2}-0.9789 \mathrm{x}+91.073 \mathrm{R}^{2}=0.97 * *$

$\square 8=0.032 \mathrm{x}^{2}-2.092 \mathrm{x}+85.906 \mathrm{R}^{2}=0.73 * *$

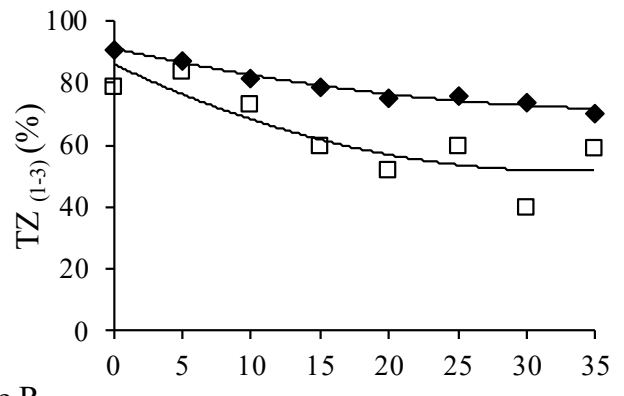

Days after stage $\mathrm{R}_{8}$

Figure 3. Average values of germination rate (GERM; a), emergence speed index (ESI; b), accelerated aging (AA; c) and tetrazolium vigor test $\left(\mathrm{TZ}_{1-3} ; \mathrm{d}\right)$, obtained in different harvesting and seed storage periods, for the BRS $820 \mathrm{RR}^{\circledR}$ soybean cultivar.
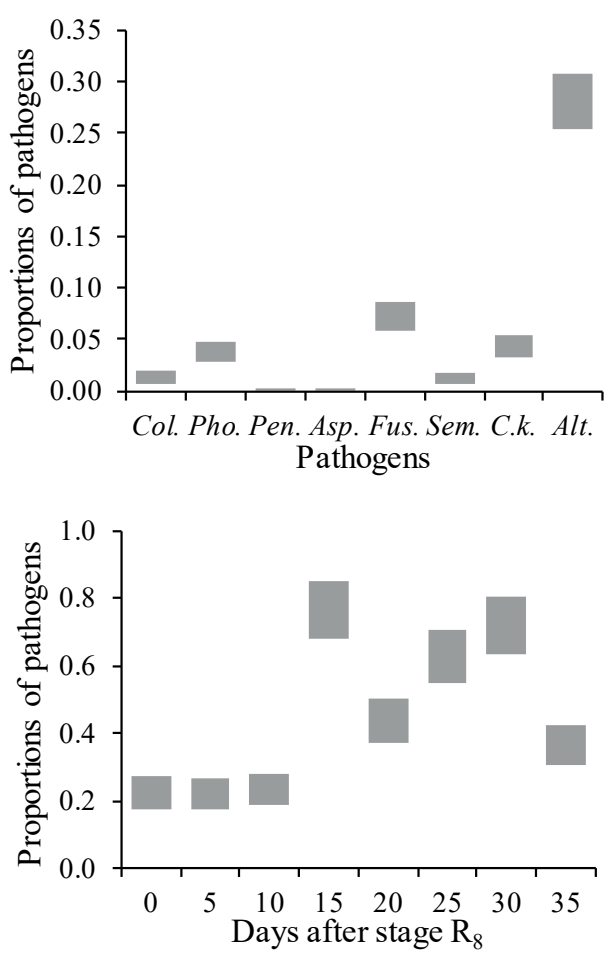

(a)

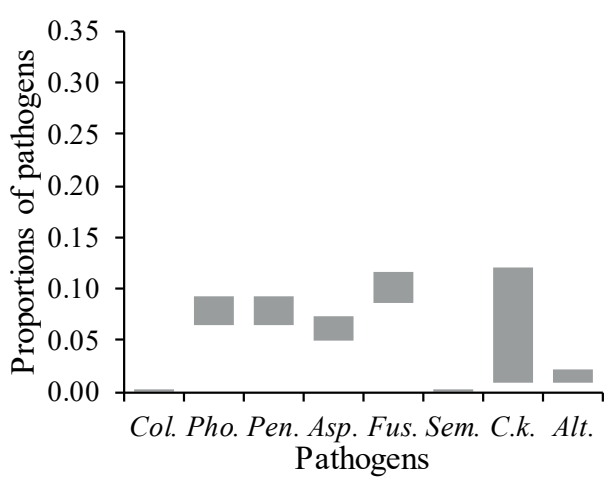

(b)

(c)

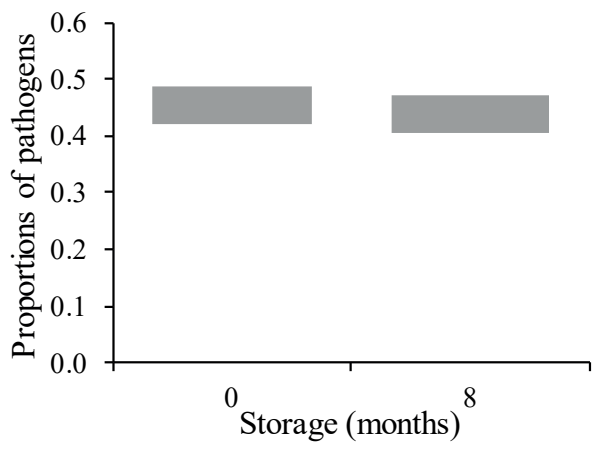

(d)

Figure 4. Confidence intervals (95\% probability) for the proportions of pathogens (Colletotrichum - Col.; Phomopsis - Pho.; Penicilium - Pen.; Aspergillus - Asp.; Fusarium - Fus.; Cercospora kikuchii - C.k.; Alternaria - Alt.), in newly harvested (a) and stored (b) seeds, in different harvesting periods (c), and total pathogens in newly harvested seeds (0 month) and stored seeds (after 8 months) (d), obtained in different harvesting and seed storage periods, for the BRS 820 RR $^{\circledR}$ soybean cultivar. 
part, to the incidence of pathogens, and the reduced physiological quality may be caused by delayed harvesting.

Regarding the average storage times, according to the confidence interval analysis for proportions, the incidence of pathogens was found to be similar both at month 0 and 8 (Figure $4 \mathrm{~d}$ ). However, differences were observed concerning the presence of the different pathogens in the nonstored and stored seeds, as previously reported. With reference to the increase of Phomopsis spp. in soybean seeds stored for 8 months (Figure 4a), when compared to the non-stored seeds (Figure 4a), possibly the lower germination rates of the stored seeds (Figure 3a) are related to the presence of this fungus.

According to Henning et al. (2005), Phomopsis spp. can reduce seed germination, especially in laboratory tests. Therefore, it has been the cause of many unsuccessful seed lots intended for sowing, even those containing seeds with high physical and genetic purity levels (Diniz et al. 2013a). This fact can be explained by the escape mechanism by which the emergent seedling releases the infected integument onto the soil, whereas, in the laboratory germination test under paper roll, the integument remains connected to the cotyledons, so the associated fungi cause seed deterioration.

\section{CONCLUSIONS}

1. Delayed harvesting of soybean seeds from 10 days after the reproductive $\mathrm{R}_{8}$ stage impairs seed vigor and germination, in addition to increasing the incidence of pathogens;

2. Regardless of the harvest period, the soybean seeds stored for 8 months show a reduction in the physiological quality of the seeds, with an increase in the incidence of Phomopsis spp.

\section{REFERENCES}

ALMEIDA, F. de A. C. et al. Estudo de técnicas para o armazenamento de cinco oleaginosas em condições ambientais e criogênicas. Revista Brasileira de Produtos Agroindustriais, v. 12, n. 2, p. 189-202, 2010.

BARBOSA, C. Z. dos R. et al. Qualidade de sementes de soja BRS Tracajá, colhidas em Roraima em função do tamanho no armazenamento. Revista Ciência Agronômica, v. 41, n. 1, p. 73-80, 2010.
BRASIL. Ministério da Agricultura, Pecuária e Abastecimento. Padrões para produção e comercialização de sementes de soja (Glycine max (L.) Merrill). Instrução normativa $\mathrm{n}^{\circ} 45$, de 17 de setembro de 2013. Diário Oficial da União, Brasília, DF, 20 set. 2013. Seção 1, p. 25.

BRASIL. Ministério da Agricultura, Pecuária e Abastecimento. Regras para análise de sementes. Brasília, DF: MAPA/ACS, 2009.

CARVALHO, C. de et al. Anuário brasileiro de sementes 2017. Santa Cruz do Sul: Gazeta, 2017.

CASTRO, E. M. et al. Physiological quality of soybean seeds produced under artificial rain in the pre-harvesting period. Journal of Seed Science, v. 38, n. 1, p. 14-21, 2016.

DANELLI, A. L. et al. Qualidade sanitária e fisiológica de sementes de soja em função do tratamento químico de sementes e no campo. Revista Ciencia y Tecnología, v. 4, n. 2, p. 29-37, 2011.

DANTAS, A. A. et al. Classificação e tendências climáticas em Lavras, MG. Ciência e Agrotecnologia, v. 31, n. 6, p. 1862-1866, 2007.

DINIZ, F. O. et al. Incidence of pathogens and field emergence of soybean seeds subjected to harvest delay. Journal of Seed Science, v. 35, n. 4, p. 478-484, 2013a.

DINIZ, F. O. et al. Physiological quality of soybean seeds of cultivars submitted to harvesting delay and its association with seedling emergence in the field. Journal of Seed Science, v. 35, n. 2, p. 147-152, 2013 b.

EMPRESA BRASILEIRA DE PESQUISA AGROPECUÁRIA (Embrapa). Centro Nacional de Pesquisa de Solos. Manual de análises químicas de solos, plantas e fertilizantes. Brasília, DF: Embrapa Solos, 2009.

FEHR, W. R. et al. Stage of development descriptions for soybeans, Glycine $\max (\mathrm{L}$.) Merrill. Crop Science, v. 11, n. 6, p. 929-931, 1971.

FRANÇA-NETO J. B. et al. A importância do uso de semente de soja de alta qualidade. Informativo Abrates, v. 20, n. 1-2, p. 37-38, 2010.

FRANÇA-NETO, J. B. et al. O teste de tetrazólio em sementes de soja. Londrina: Embrapa, 1998.

HENNING, A. A. et al. Patologia e tratamento de sementes: noções gerais. 2. ed. Londrina: Embrapa Soja, 2005.

KRZYZANOWSKI, F. C. et al. Teste do hipoclorito de sódio para semente de soja. Londrina: Embrapa Soja, 2004.

KRZYZANOWSKI, F. C. et al. Vigor de sementes: conceitos e testes. Londrina: Abrates, 1999. 
LIMA, W. A. A. D. et al. Retardamento da colheita e qualidade de sementes de soja. Revista Brasileira de Sementes, v. 29, n. 1, p. 186-192, 2007.

MAGUIRE, J. D. Speed of germination-aid in selection and evaluation for seedling emergence and vigor. Crop Science, v. 2, n. 2, p. 176-177, 1962.

MARCANDALLI, L. H. et al. Épocas de aplicação de dessecantes na cultura da soja: qualidade fisiológica de sementes. Revista Brasileira de Sementes, v. 33, n. 2, p. 241-250, 2011.

MARCOS FILHO, J. Fisiologia de sementes de plantas cultivadas. Piracicaba: Fealq, 2005.

MARCOS FILHO, J. Teste de envelhecimento acelerado. In: KRZYZANOWSKI, F. C.; VIEIRA, R. D.; FRANÇANETO, J. B. (Eds.). Vigor de sementes: conceitos e testes Londrina: Abrates, 1999.
MINUZZI, A. et al. Qualidade de sementes de quatro cultivares de soja, colhidas em dois locais no Estado do Mato Grosso do Sul. Revista Brasileira de Sementes, v. 32, n. 1, p. 176-185, 2010.

RAMALHO, M. A. P. et al. Experimentação em genética e melhoramento de plantas. Lavras: Ed. UFLa, 2012.

SMANIOTTO, T. D. S. et al. Qualidade fisiológica das sementes de soja armazenadas em diferentes condições. Revista Brasileira de Engenharia Agrícola e Ambiental, v. 18, n. 4, p. 446-453, 2014.

TSUKAHARA, R. Y. Produtividade de soja em consequência do atraso da colheita e de condições ambientais. Pesquisa Agropecuária Brasileira, v. 51, n. 8, p. 905-915, 2016.

XAVIER, T. S. et al. Época de colheita na qualidade de sementes de genótipos de soja. Comunicata Scientiae, v. 6, n. 2, p. 241-245, 2015. 